\title{
Managing Resident Workforce and Residency Training During COVID-I9 Pandemic: Scoping Review of Adaptive Approaches
}

This article was published in the following Dove Press journal:

Advances in Medical Education and Practice

Lemi Belay Tolu (D)

Garumma Tolu Feyissa $\mathbb{D}^{2}$

Alex Ezeh (iD ${ }^{2}$

Wondimu Gudu (D)

'Saint Paul's Hospital Millennium Medical College, Department of Obstetrics and Gynecology, Addis Ababa, Ethiopia;

${ }^{2}$ Dornsife School of Public Health, Drexel University, Philadelphia, PA, USA
Correspondence: Lemi Belay Tolu Email lemi.belay@gmail.com
Objective: To review available adaptive residency training approaches and management of the resident workforce in different residency programs amid COVID-19 pandemic.

Materials and Methods: Websites of different professional associations and international or national specialty accreditation institutions were searched. We looked for English studies (any form), reviews or editorials, perspectives, short or special communications, and position papers on residency education during the COVID-19 pandemic. PubMed, EMBASE, and Google Scholar were also searched using keywords. Two independent reviewers extracted data using a customized tool that was developed to record the key information relevant to the review question. The two authors resolved their difference in data extraction by discussion. Results: We identified 13 documents reporting on residency education during pandemics. Three were articles, 5 short or special communications, and the rest editorials and perspectives. We divided the data obtained into six thematic areas: resident staffing, clinical education, surgical education, didactic teaching, research activity, and accreditation process. Conclusion: Residency programs must reorganize the resident's staffing and provide appropriate training to ensure the safety of residents during the pandemic. There are feasible adaptive approaches to maintaining residency training in the domains of didactic teaching, clinical education, and some research activities. Although some innovative virtual surgical skills training methods are implemented in limited surgical residency disciplines, their effectiveness is not well examined. Guidance and flexibility of the accreditation bodies in ensuring the competency of residents is one component of the adaptive response.

Keywords: residency, COVID-19, SARS-CoV-2, didactic, clinical, surgery, accreditation

\section{Introduction}

The World Health Organization (WHO) declared the COVID-19 outbreak as a pandemic on 11 March 2020. ${ }^{1,2}$ Since then many countries have implemented different COVID-19 mitigation measures including physical distancing and lockdown. As part of international crises in the health care system, many residency trainings are being affected by SARS-COV-2 and mitigation measures implemented. Any gathering with more than 5 people recently recommended to be avoided by the Centers for Disease Control. ${ }^{3}$ As a result, in-person residency academic activities should be avoided disrupting all pillars of residency education. The clinical education and handson training are affected by the disruption of formal health care delivery like elective surgeries, disruption of skill-based teaching activities, and deployment of residents to COVID-19 related service. Many government institutions and professional 
associations including the American College of Surgeons (ACS) is recommending against the continuation of elective surgery ${ }^{4}$ and minimizing participants in any operation which will undoubtedly decrease resident case volume. Academics and didactic teaching of residents were also disrupted because of the interruption of bedsides, morbidity and mortality conferences, rounds, and seminar teaching. The same is true for the resident's research activity. Additionally, the rotation of residents between different hospitals and between two sites within the same hospital should also be limited.

Many programs have restructured their call schedules to reduce their number of in-house residents, while others face the possibility of resident redeployment to service with greater demand (eg, trauma, intensive care). Residents during their dedicated research years grapple with institutional suspensions of critical research activities, which threaten their scientific progress. ${ }^{5}$ Given all these sudden changes, residents, especially in the surgical discipline, will see a significant reduction in resident's exposure to all pillars of their training, with no clear endpoint. This might result in an overall reduction in the experience and competency of the residents posing a problem on the accreditation process. This huge burden for residency directors and consultants, yet there are no universal or multi-institutional recommendations.

These unfathomable circumstances require flexibility and creativity with novel interventions to ensure training is provided without compromising quality. These need to be done while maintaining the safety of the residents, consultants, and patients. Although there is no substitute for time in the operating room for surgical disciplines, residency programs have been quick to migrate the didactic components of the training curriculum online. Webbased educational platforms have become the frontier of innovation in the era of COVID-19. Learning experiences well suited for online platforms include video teleconferencing, lectures, case conferences, and journal clubs, among many others. ${ }^{6}$ There have also been efforts to ameliorate the for the diminished surgical exposure by implementing virtual surgery atlases, live surgical video. ${ }^{7}$

Considering the above facts, we did a scoping review to synthesize evidence on adaptive (innovative) ways of maintaining residency education activities during the COVID-19 pandemic.

\section{Research Questions}

1. What are available adaptive ways to continue residency clinical, didactic, and surgical teaching and research activity during COVID-19?
2. What are adaptive means (effective utilization of resident task force amid the Covid-19 pandemic) for resident staffing and clinical coverage maintaining safety and patient protection?

3. What is the guidance (response) regarding residency accreditation amid the Covid-19 Pandemic?

\section{Materials and Methods}

\section{Search Strategy}

We looked for websites of different specialty associations and international or national specialty accreditation institutions. We looked for the website and publication of the following: American Board of Orthopedic Surgery (ABOS), Association of American Medical Colleges (AAMC), Accreditation Council for Graduate Medical Education (ACGME), European Academy of Pediatrics, American Board of Medical Specialties, American Board of Neurological Surgery, Congress of Neurological Surgeons, American Association of Neurological Surgeons, American College of Surgeons, Council on Podiatric Medical Education (CPME), European Federation of Internal Medicine (EFIM), American Board of Obstetrics and Gynecology (ABOG), American Board of Radiology (ABR), European Board of Radiology (EBR), European Board of Ophthalmology (EBO), European Board of Urology (UBU) and European Board \& College of Obstetrics and Gynecology (EBCOG).

Additionally, we also developed a search strategy using keywords residency, residents, education, training, COVID19 to look for available documents. We searched the following databases: PubMed, EMBASE, and Google Scholar (Table 1). We prepared this scoping review according to Preferred Reporting Items for a systematic scoping review ${ }^{8}$ (Table S1). We used the following inclusion parameters:

\section{Population}

We included residents on training programs in different specialty programs.

\section{Concepts}

The review considered studies, reviews, position statements, or recommendations addressing the resident's education program during the pandemic.

\section{Context}

Included worldwide records or recommendations addressing resident's education programs during the pandemic. 
Table I Search Conducted on May 2, 2020, MEDLINE (Ovid)

\begin{tabular}{|c|c|c|}
\hline Number & Search Query & Result \\
\hline I & 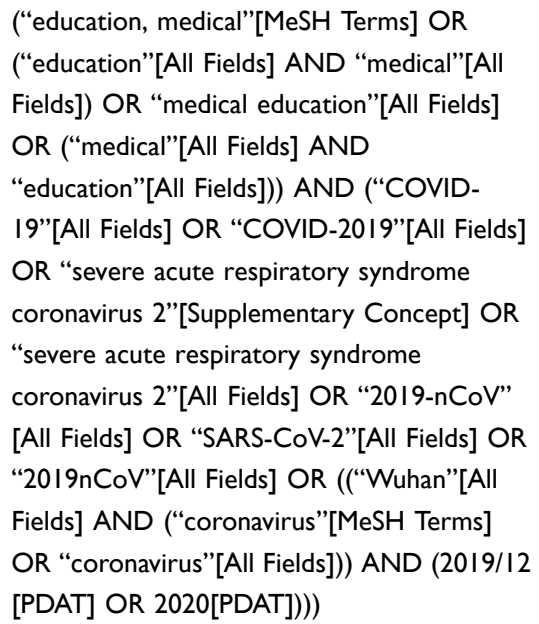 & 729 \\
\hline 2 & Limit I to English AND Human AND I year & 300 \\
\hline
\end{tabular}

\section{Types of Documents/Records}

We considered studies (any form), reviews or editorials, perspectives, short or special communications, and position papers on residency education during the pandemic. The search is limited to the past year as the outbreak happened in December 2019.

\section{Data Extraction and Synthesis}

Two independent reviewers extracted data using a customized tool that was developed to record the key information relevant to the review question. Types of record, author of the document, field of residency training, the domain of residency education, month and year of publication, and recommendations of the documents were extracted. The difference between the two authors on data extraction was resolved by discussion. We searched for the resident's clinical teaching, didactic, and research activity during the COVID-19 pandemic. We categorized identified evidence into the following thematic areas: staffing, safety, and clinical coverage, clinical education, surgical education, didactic teaching, research activity, and accreditation process. We described findings narratively (Table 2: Data extraction table).

\section{Ethical Considerations}

Formal ethical permission is not required for this review and all data used were included in the manuscript and supplementary material.

\section{Results and Discussion}

We reviewed different websites, Google scholar, PubMed, and EMBASE. We identified a total of 404 records. After removing duplicates, we screened titles and abstracts of 334 documents and retained 34 papers for full-text review. Based on the inclusion criteria, we included 13 records in the scoping review (Figure 1).

\section{Characteristics of Included Records/ Documents}

We retained 13 documents for scoping review according to predefined inclusion criteria. Three were articles, 5 short or special communications and the rest editorials and perspectives (Table 3 below)

Staffing, safety and clinical service organization (resident safety, emotional and psychological integrity amid COVID-19)

We identified nine documents reporting on resident staffing and safety amid COVID-19., ${ }^{5,7-15}$ Reorganizing residents staffing to ensure safety during the pandemics is very important. Besides residents must be trained in infection prevention in a clinical setting including appropriate use of protective equipment and personal hygiene. ${ }^{13,16}$ These trainings can be conducted online via different virtual platforms. ${ }^{7,9,16}$ Many recommend creating social media platforms communications to keep residents and staff stay in communication with each other to ease fear and anxiety about the pandemic. ${ }^{13,14}$ Crosby and Sharma on Otolaryngology residency training recommended virtual sessions for social connectedness to help residents suffering from the added pandemic anxiety of worrying about not only their safety but also for the safety of patients, friends, and family. To preserve the workforce and minimize transmission of the virus among residents many residency programs have designed different innovative staffing mechanisms. Most of the resident staffing techniques amid COVID-19 involves significantly reducing the number of residents staying in hospital by dividing them into two groups and rotating every 1-2 weeks. One group involved in clinical service (active inpatient or on service group) and the other group will stay at home remotely providing tele supervision, consultation, and arrange different virtual teaching programs. ${ }^{5,7,10,11,13-15}$ Naser et al reported experience of restructuring of general surgery residents during pandemics into three exclusive groups (inpatient, operative, and clinic) rotating weekly to practice appropriate physical distancing and reduce the possibility of transmission among residents. ${ }^{12}$ 
Table 2 Data Abstraction Form

\begin{tabular}{|c|c|c|c|c|c|c|}
\hline \multicolumn{7}{|c|}{ Intervention Areas } \\
\hline Author & $\begin{array}{l}\text { Staffing, safety, and clinical } \\
\text { coverage }\end{array}$ & $\begin{array}{l}\text { Didactic } \\
\text { education }\end{array}$ & Surgical education & Clinical education & $\begin{array}{l}\text { Research } \\
\text { activity }\end{array}$ & Accreditation \\
\hline $\begin{array}{l}\text { Stambough } \\
\text { et al }\end{array}$ & $\begin{array}{l}\text { Under emergency declaration } \\
\text { residents give priority to patient } \\
\text { care per hospital arrangement. }\end{array}$ & $\begin{array}{l}\text { Virtual lectures } \\
\text { and journal club }\end{array}$ & $\begin{array}{l}\text { surgical video } \\
\text { databases, such as the } \\
\text { OVT and OVT plus } \\
\text { cadaver and bone- } \\
\text { substitute simulations }\end{array}$ & $\begin{array}{l}\text { Suspend clinical } \\
\text { teaching }\end{array}$ & Not reported & $\begin{array}{l}\text { Suspended but } \\
\text { states that } \\
\text { graduation is left } \\
\text { to the discretion } \\
\text { of the program } \\
\text { director. }\end{array}$ \\
\hline $\begin{array}{l}\text { Bambakidis } \\
\text { et al }\end{array}$ & $\begin{array}{l}\text { Decreasing resident staffing to } 50 \% \\
\text { of normal and allowing teams to } \\
\text { rotate on for a week at a time. }\end{array}$ & $\begin{array}{l}\text { Online } \\
\text { education. }\end{array}$ & $\begin{array}{l}\text { Surgical cases limited } \\
\text { to one resident and } \\
\text { the rest } \\
\text { videoconference. }\end{array}$ & $\begin{array}{l}\text { One resident in place } \\
\text { and teleconference }\end{array}$ & Not stated & Not stated \\
\hline $\begin{array}{l}\text { Tomlinson } \\
\text { et al }\end{array}$ & Not reported & Virtual didactic & $\begin{array}{l}\text { Neurosurgical Atlas } \\
\text { and } 3 D \text { models and } \\
\text { web-based } \\
\text { simulations. }\end{array}$ & $\begin{array}{l}\text {-grand round webinars } \\
\text {-live interactive } \\
\text { Virtual Visiting } \\
\text { Professor sessions }\end{array}$ & Not reported & Not reported. \\
\hline $\begin{array}{l}\text { John } \\
\text { R Potts }\end{array}$ & Tele-supervision & Not reported & Not reported & Not reported & Not reported & $\begin{array}{l}\text { postpone } \\
\text { all scheduled and } \\
\text { requested } \\
\text { accreditation site } \\
\text { visits }\end{array}$ \\
\hline Vargo et al & $\begin{array}{l}\text { Limited at hospital and consultation } \\
\text { from home(rotation) }\end{array}$ & Virtual didactic & $\begin{array}{l}\text { high-priority elective" } \\
\text { robotic cases with } \\
\text { intraoperative } \\
\text { surgical principles. }\end{array}$ & $\begin{array}{l}\text { Academic } \\
\text { Conference. morning } \\
\text { sessions, journal club }\end{array}$ & Not specified. & Not stated. \\
\hline $\begin{array}{l}\text { Schwartz } \\
\text { et al }\end{array}$ & $\begin{array}{l}\text { “active-duty inpatient” and } \\
\text { "remotely-working." (2-week cycle) }\end{array}$ & $\begin{array}{l}\text { Protected time } \\
\text { for virtual } \\
\text { teaching }\end{array}$ & $\begin{array}{l}\text { Virtual reality or } \\
\text { simulation training. }\end{array}$ & $\begin{array}{l}\text { post-clinic virtual } \\
\text { conference between } \\
\text { attendings and on- } \\
\text { service residents } \\
\text { (video-enabled } \\
\text { telemedicine) }\end{array}$ & $\begin{array}{l}\text { Video-enabled } \\
\text { virtual research } \\
\text { meetings }\end{array}$ & Not stated. \\
\hline Nassar et al & $\begin{array}{l}3 \text { exclusive patient care domains: } \\
\text { inpatient, operative, and clinic } \\
\text { rotating every } 7 \text { th day. }\end{array}$ & Not reported & Not reported & Not reported & Not reported & Not reported. \\
\hline $\begin{array}{l}\text { Rakowsky } \\
\text { et al }\end{array}$ & Not reported. & $\begin{array}{l}\text { Remote learning/ } \\
\text { virtual. }\end{array}$ & Not reported & $\begin{array}{l}\text { email-based clinical } \\
\text { vignettes with } \\
\text { associated questions } \\
\text { and clinical images. }\end{array}$ & Not reported. & Not reported \\
\hline Chong et al & $\begin{array}{l}\text { Safety assured residents divided } \\
\text { into } 2 \text { groups, (every Iwk) with one } \\
\text { group reporting to clinical service, } \\
\text { and the other assigned to home } \\
\text { learning; PPE, }\end{array}$ & Virtual learning & Not applicable & $\begin{array}{l}\text { case-based conferences } \\
\text { and lectures } \\
\text { by videocast, online } \\
\text { educational resources, } \\
\text { teleconferencing, }\end{array}$ & Home-based & $\begin{array}{l}\text { minimum } \\
\text { requirements for } \\
\text { graduation; } \\
\text { readdressing } \\
\text { credentialing } \\
\text { requirements }\end{array}$ \\
\hline $\begin{array}{l}\text { Crosby } \\
\text { et al }\end{array}$ & $\begin{array}{l}\text {-appropriate PPE, } \\
2 \text { groups (clinical activities, work } \\
\text { from home). } \\
\text {-Mental health (virtual sessions for } \\
\text { social connectedness) }\end{array}$ & $\begin{array}{l}\text { a nationwide } \\
\text { didactic } \\
\text { curriculum, } \\
\text { virtual sessions }\end{array}$ & $\begin{array}{l}\text { online training } \\
\text { modules, skills labs }\end{array}$ & $\begin{array}{l}\text { Teleconferencing } \\
\text { (not detailed) }\end{array}$ & $\begin{array}{l}\text { a research } \\
\text { curriculum } \\
\text { implemented. }\end{array}$ & $\begin{array}{l}\text { Additional didactic } \\
\text { sessions to make } \\
\text { sure adequate } \mathrm{KI} \\
\text { according to } \\
\text { ACGME }\end{array}$ \\
\hline
\end{tabular}

(Continued) 
Table 2 (Continued).

\begin{tabular}{|l|l|l|l|l|l|l|}
\hline Intervention Areas & $\begin{array}{l}\text { Sidactic } \\
\text { coverage }\end{array}$ & Surgical education & Clinical education & $\begin{array}{l}\text { Research } \\
\text { activity }\end{array}$ & Accreditation \\
\hline Author & Stucation & $\begin{array}{l}\text { Digital learning } \\
\text { resources } \\
\text { Online } \\
\text { virtual }\end{array}$ & Not applicable & $\begin{array}{l}\text { virtual live or recorded } \\
\text { conferences }\end{array}$ & $\begin{array}{l}\text { Discuss with } \\
\text { a mentor on } \\
\text { other projects } \\
\text { which can be } \\
\text { done from } \\
\text { home }\end{array}$ & $\begin{array}{l}\text { Delayed } \\
\text { examination and } \\
\text { credentialing } \\
\text { Work with } \\
\text { accreditation } \\
\text { bodies }\end{array}$ \\
\hline $\begin{array}{l}\text { Amparore } \\
\text { et al }\end{array}$ & Not reported & Not reported & $\begin{array}{l}\text { Tele mentoring of } \\
\text { surgical procedures } \\
\text { simulation }\end{array}$ & Telemedicine & Not reported & Not reported \\
\hline $\begin{array}{l}\text { Robert } \\
\text { Connor } \\
\text { et al }\end{array}$ & Maintain the safety of residents & $\begin{array}{l}\text {-flipped virtual } \\
\text { classroom } \\
\text {-Teleconferencing }\end{array}$ & $\begin{array}{l}\text {-online practice } \\
\text { questions, } \\
- \text { simulation lab and } \\
\text {-facilitated use of } \\
\text { surgical videos }\end{array}$ & $\begin{array}{l}\text { - telemedicine clinics } \\
\text { with resident }\end{array}$ & Nele-conferencing & \\
\hline
\end{tabular}

Resident clinical education (Morning, case presentations, bedsides, round, seminars (management session), journal club)

Few residency programs suspend resident clinical teachings ${ }^{9}$ while many residency training programs designed alternative innovative technologies to maintain resident clinical education during COVID-19 pandemic. ., $^{511,13-15,17,18}$ Bambakidis reported experience of neurosurgery at Cleveland Medical Center that one or two residents to be in place with patient discussion with the team by teleconference. Similarly, Schwartz et al recommended post-clinic videoenabled telemedicine between attendings and on-service residents for clinical education. ${ }^{5}$ Ground round webinars live interactive virtual visiting professor sessions, virtual academic conference, case-based conferences and morning session webinar, journal club webinar, email-based clinical vignettes with associated questions and clinical images, virtual live or recorded conferences were being used for clinical education in a different residency program. ${ }^{7,11,13-15,17,18}$ In these different virtual teachings used in different residency programs, many recommended using different mechanisms such as using tools that promote interaction and audience participation. ${ }^{6,13}$

\section{Resident Surgical Education (Hands-on Training)}

The shutdown of elective surgeries caused a dramatic reduction of case volume and operating room exposure time which will not be replaced by simple academic conferences and telehealth. Many residency programs had instituted alternative surgical teaching methods during COVID-19. 5,7,9,11,14,18 For example, Stambough et al reported on orthopedic surgical education by using videos, such as the Orthopedic Video Theater (OVT) and Orthopedic Video Theater plus (OVT plus), cadaver and bone-substitute simulations. ${ }^{9}$ Tomlinson reported Neurosurgical Atlas and 3D models and web-based simulations as innovative neurosurgical hands-on training amid COVID-19 at the University of Rochester Medical Center, New York. ${ }^{7}$ Neurosurgical Atlas is a free, online, multimedia resource focused on operative techniques and microsurgical anatomy. Vargo et al reported on the experience of Cleveland Clinic on videoconference teaching of high-priority elective" robotic cases with intraoperative surgical principles for general urology residency program's. ${ }^{11}$ Department of Orthopedics, Emory University School of Medicine are using virtual reality or simulation training for orthopedic surgical education. Exemplary virtual reality and surgical simulators platforms have been developed for total knee and total hip arthroplasty surgery. ${ }^{5}$ Tele mentoring of surgical procedures simulation, online training modules, skills labs, online practice questions and facilitated use of surgical videos were among other methods used for surgical education by different residency programs. ${ }^{6,14,18}$

\section{Resident Didactic Teaching (Lectures)}

Nine of identified records reported on alternative virtual didactic residency education during COVID-19. ${ }^{19}$ These virtual didactics include virtual lectures, journal clubs, flipped 


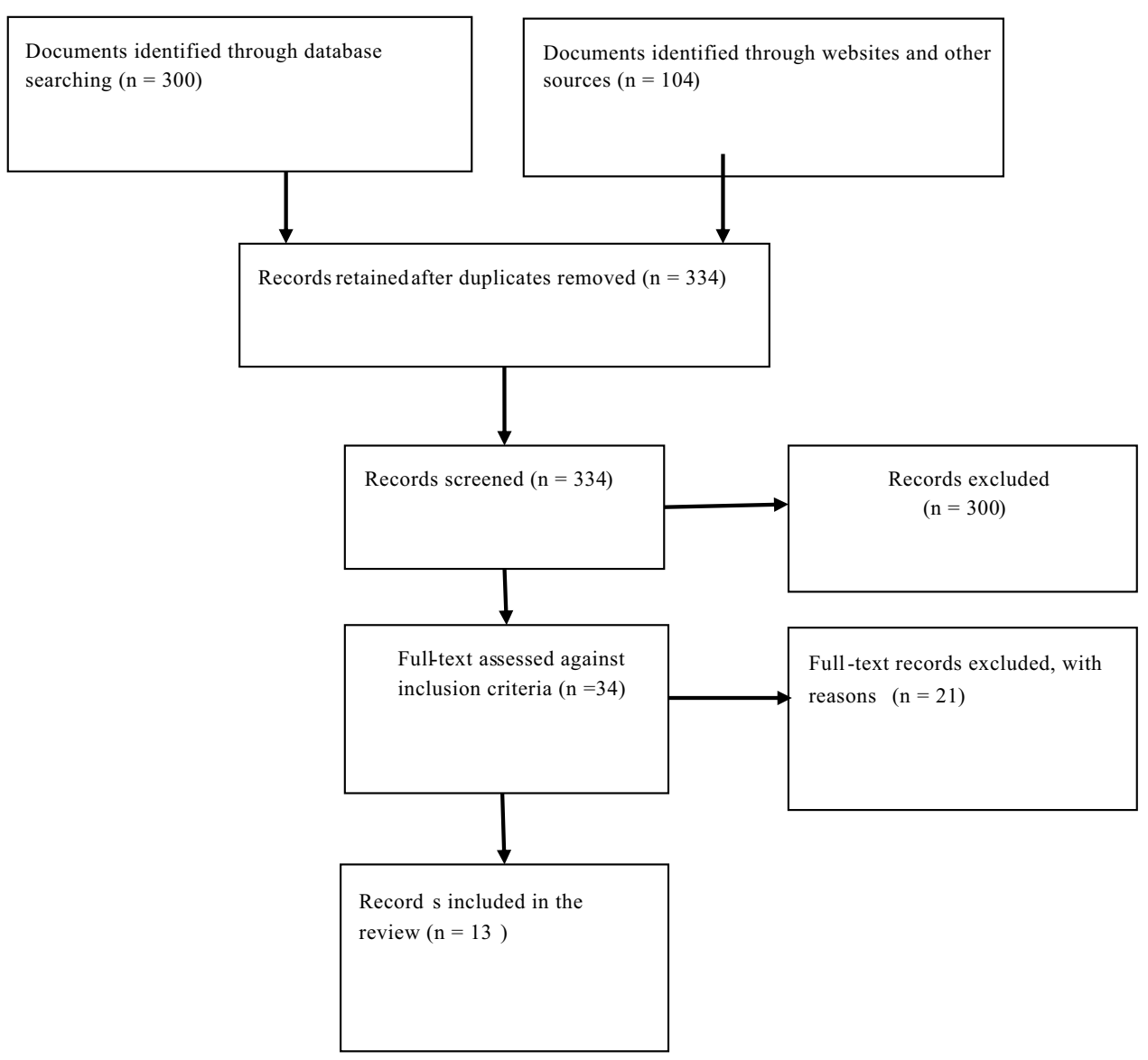

Figure I Prisma flow diagram showing study selection process.

virtual classrooms, and teleconferences. The University of California uses novel methods of social-media-based Facebook platform groups titled "ABSITE Daily". The platform is used to provide practice questions and discussion platforms to prepare trainees for the American Board of Surgery In-Training Examination (ABSITE). This platform in addition to allowing daily exposure to practice questions provides an avenue of discussion of surgical topics without any need for in-person meetings. ${ }^{6}$

\section{Resident Research Activity}

Research activity has been disrupted at many institutions during the pandemics. To overcome such factors, some residency programs are using alternative ways of continuing residency research programs. ${ }^{5,13-15}$ Video enabled virtual research meetings and encouraging residents working from home (nonclinical resident) to develop research projects during the off-work week is recommended. This can be done by weekly virtual meetings with their research mentor. Southern Illinois University School of Medicine Otolaryngology Department is using such methods to maintain resident's research activity. They designed in a way that, weekly virtual research meeting is held for all residents. On each meeting, one resident presents details of the update on their project and they review all the in-depth of the research methodology including statistical analyses specific to that project. ${ }^{14}$ Four USA based radiology residency programs encourage research mentors and their trainees to have ongoing discussions on other projects during the pandemic, including securing funding and reshaping works-inprogress into publishable or presentable material. ${ }^{15}$

\section{Accreditation Process}

The pandemic is affecting the current accreditation process and will have an undue effect to get minimum case log or minimum activity volume (MAV) required to sit for board examinations graduate. ${ }^{16}$ America Board of Orthopedic Surgery (ABOS) suspended all current accreditation processes but states that graduation decisions should be decided by the program director. ${ }^{9}$ ABOS swiftly responded to the pandemic crisis by adding the "time away" from residency training per academic year to 
Table 3 Characteristics of Included Documents or Records

\begin{tabular}{|c|c|c|c|c|}
\hline Author & $\begin{array}{l}\text { Type of } \\
\text { Document }\end{array}$ & Country and Affiliate Institution & $\begin{array}{l}\text { Type of } \\
\text { Residency } \\
\text { Training }\end{array}$ & Areas of Intervention \\
\hline Stambough et $\mathrm{al}^{9}$ & $\begin{array}{l}\text { Short } \\
\text { communication. }\end{array}$ & USA (related to America Board Orthopedic Surgery) & $\begin{array}{l}\text { Orthopedic } \\
\text { surgery. }\end{array}$ & $\begin{array}{l}\text {-Accreditation. } \\
\text {-Clinical teaching } \\
\text {-Didactic (virtual lectures } \\
\text { and journal clubs) } \\
\text {-surgical teaching. }\end{array}$ \\
\hline Bambakidis et $\mathrm{al}^{7}$ & Editorial. & University Hospitals Cleveland Medical Center, USA & Neurosurgery & $\begin{array}{l}\text { Clinical education } \\
\text { Didactic teaching } \\
\text { Surgical education } \\
\text { Resident staffing. }\end{array}$ \\
\hline Tomlinson $^{7}$ & Editorial. & $\begin{array}{l}\text { University of Rochester Medical Center, New York/USA and } \\
\text { Indiana University, Indianapolis, Indiana }\end{array}$ & Neurosurgery & $\begin{array}{l}\text { Clinical education } \\
\text { Didactic teaching } \\
\text { Surgical education }\end{array}$ \\
\hline John R Potts ${ }^{10}$ & Special article & USA, ACGME & $\begin{array}{l}\text { Accreditation } \\
\text { council for all. }\end{array}$ & $\begin{array}{l}\text { Accreditation. } \\
\text { Resident staffing }\end{array}$ \\
\hline Vargo et al ${ }^{\prime \prime}$ & $\begin{array}{l}\text { Short } \\
\text { communication. }\end{array}$ & Cleveland Clinic Akron General Urology Residency Program's & Urology surgery. & $\begin{array}{l}\text { Clinical education } \\
\text { Didactic teaching } \\
\text { Surgical education } \\
\text { Resident staffing. }\end{array}$ \\
\hline Schwartz et al $\left.\right|^{5}$ & $\begin{array}{l}\text { Short } \\
\text { communication }\end{array}$ & $\begin{array}{l}\text { Department of Orthopedics, Emory University School of Medicine, } \\
\text { USA. }\end{array}$ & orthopedic surgery & $\begin{array}{l}\text { Clinical education } \\
\text { Didactic teaching } \\
\text { Surgical education } \\
\text { Resident staffing. } \\
\text { Research activity. }\end{array}$ \\
\hline Nassar et al ${ }^{12}$ & $\begin{array}{l}\text { Special } \\
\text { Communication }\end{array}$ & Department of Surgery, University of Washington, USA & $\begin{array}{l}\text { General Surgery } \\
\text { Residency }\end{array}$ & Resident staffing. \\
\hline Rakowsky et al ${ }^{17}$ & $\begin{array}{l}\text { Short } \\
\text { communication }\end{array}$ & Israel Deaconess Medical Center & $\begin{array}{l}\text { Internal Medicine } \\
\text { Program }\end{array}$ & $\begin{array}{l}\text { Didactic teaching } \\
\text { Clinical education. }\end{array}$ \\
\hline Chong et $\mathrm{al}^{13}$ & Article & US, UC San Diego School of Medicine & Radiology & $\begin{array}{l}\text { Clinical teaching } \\
\text { Didactic (virtual lectures and } \\
\text { journal clubs) } \\
\text { The resident Taskforce and } \\
\text { safety } \\
\text { Research } \\
\text { Accreditation }\end{array}$ \\
\hline Crosby et al $\left.\right|^{14}$ & Article & The US, Southern Illinois University School of Medicine & Otolaryngology & $\begin{array}{l}\text { Surgical education } \\
\text { Accreditation } \\
\text { Resident Safety } \\
\text { Research } \\
\text { Didactic } \\
\text { Clinical education }\end{array}$ \\
\hline Alvin etal ${ }^{15}$ & Perspectives & US, 4 radiology programs & Radiology & $\begin{array}{l}\text { Taskforce Mx } \\
\text { Didactic } \\
\text { Clinical } \\
\text { Research accreditation }\end{array}$ \\
\hline Amparore et al ${ }^{18}$ & Article & Italy, all universities with urology programs & Urology & $\begin{array}{l}\text { Surgery } \\
\text { Clinical }\end{array}$ \\
\hline
\end{tabular}

(Continued) 
Table 3 (Continued).

\begin{tabular}{|l|l|l|l|l|}
\hline Author & $\begin{array}{l}\text { Type of } \\
\text { Document }\end{array}$ & Country and Affiliate Institution & $\begin{array}{l}\text { Type of } \\
\text { Residency } \\
\text { Training }\end{array}$ & Areas of Intervention \\
\hline Robert Connor et al & perspectives & The University of California at San Francisco & surgery & $\begin{array}{l}\text { Safety of residents } \\
\text { Didactic } \\
\text { Clinical } \\
\text { Surgical }\end{array}$ \\
& & & & \\
\hline
\end{tabular}

provide flexibility and also stressed that program directors to work to make sure residents meet ACGME minimum case requirements. ${ }^{9,16}$ As of March 9, ACGME has also indefinitely postponed all scheduled and requested accreditation site visits. ${ }^{16}$ The American Board of Radiology has delayed the board certification test up to September 1, $2020 .^{20}$ Such postponed graduation and credentialing might impact subsequent onboarding time for incoming residents. Radiology and Otolaryngology residency programs in the USA suggested minimum requirement for graduation, using additional didactic sessions to fulfill the requirements and closely working with accreditation bodies and with their local clinical competency committee to solve the problems. ${ }^{13-15}$

\section{Conclusions}

\section{Implications for Practice}

The undue effect of the COVID-19 pandemic on residency training is well recognized across many residency programs. Residency directors must reorganize residents staffing to ensure health and safety during the pandemics. Besides residents must be trained in infection prevention in a clinical setting including appropriate use of personal protective equipment (PPE) and personal hygiene. Different innovative alternative teaching methods were evolving to substitute the former face to face teaching to maintain residency didactic, clinical, surgical education, and research activity. During COVID-19 pandemic alternative teaching methods such as video teleconferencing, virtual lectures, virtual ground rounds, virtual case conferences, journal club webinars, e-learning modules, online textbooks, email clinical vignettes with associated questions and clinical images, live interactive virtual visiting professor sessions, video database platforms, Podcasts, online blogs, Webinars, E-literature searches, surgical simulators, and virtual reality (VR) platforms can be used to maintain all pillars of residency education. Residency directors also must closely work with accreditation bodies and with their local clinical competency committee to ease the impact of COVID-19 on the accreditation process. One drawback of innovative teaching methods is the necessity of having a good internet connection. Therefore, residency directors in developing where there is no stable connection should work with responsible bodies to make sure that residents have access to the internet.

\section{Implications for Research}

This scoping review is very timely putting together evidence for keeping residency training amid COVID-19 pandemic. However, the current review has its limitations that worth considerations. The documents included in this scoping review were mainly from surgical areas such as orthopedics, neurosurgery, urology, otolaryngology, and radiology residency. This is because of a paucity of data published on the subject matter with the possibility of publication bias. Besides, the included studies where not critically appraised. Nevertheless, with the above limitations in mind, the scoping review provides insight into the necessity of innovative and alternative methods of residency education. Such preliminary evidence might be an input to generate hypothesis or design rigorous research projects that will inform practice and policy decisions. Therefore, we recommend the generation of more evidence on innovative alternative teaching methods used worldwide across different residency programs which might be used to shape future residency education.

\section{Author Contributions}

Conceptualization: Wondimu Gudu Jeldu, Lemi Belay Tolu Alex Ezeh, Garumma Tolu Feyissa

Data curation: Lemi Belay Tolu, Wondimu Gudu Jeldu, Alex Ezeh, Garumma Tolu Feyissa

Formal analysis: Lemi Belay Tolu, Wondimu Gudu Jeldu, Alex Ezeh, Garumma Tolu Feyissa

Investigation: Lemi Belay Tolu, Wondimu Gudu Jeldu, Alex Ezeh, Garumma Tolu Feyissa

Methodology: Lemi Belay Tolu, Wondimu Gudu Jeldu, Alex Ezeh, Garumma Tolu Feyissa 
Project administration: Lemi Belay Tolu, Wondimu Gudu Jeldu, Garumma Tolu Feyissa

Resources: Lemi Belay Tolu, Wondimu Gudu Jeldu, Alex Ezeh, Garumma Tolu Feyissa

Software: Lemi Belay Tolu, Wondimu Gudu Jeldu, Alex Ezeh, Garumma Tolu Feyissa

Supervision: Lemi Belay Tolu, Wondimu Gudu Jeldu, Alex Ezeh, Garumma Tolu Feyissa

Validation: Lemi Belay Tolu, Wondimu Gudu Jeldu, Alex Ezeh, Garumma Tolu Feyissa.

\section{Funding}

We authors did not receive any funding support from any organization for this review.

\section{Disclosure}

The authors have no conflict of interest to declare.

\section{References}

1. Zambrano LI, Fuentes-Barahona IC, Bejarano-Torres DA. et al. A pregnant woman with COVID-19 in Central America. Travel Med Infect Dis. 2020; 101639. doi:10.1016/j.tmaid.2020.101639

2. Chen $\mathrm{H}$, Guo J, Wang C, et al. Clinical characteristics and intrauterine vertical transmission potential of COVID-19 infection in nine pregnant women: a retrospective review of medical records. Lancet. 2020;395 (10226):809-815. doi:10.1016/S0140-6736(20)30360-3

3. CDC. Centers for disease control and prevention communities, schools, workplaces, \& events; 2020. Available from: https://www. cdc.gov/coronavirus/2019-ncov/community/large-events/index.html. Accessed July 27, 2020.

4. Chen S, Liao E, Cao D, Gao Y, Sun G, Shao Y. Clinical analysis of pregnant women with 2019 novel coronavirus pneumonia. J Med Virol. 2020.

5. Schwartz AM, Wilson JM, Boden SD, Moore Jr TJ, Bradbury Jr TL, Fletcher ND. Managing resident workforce and education during the COVID-19 pandemic: evolving strategies and lessons learned. JBJS Open Access. 2020;5(2):e0045. doi:10.2106/JBJS.OA.20.00045

6. Chick RC, Clifton GT, Peace KM, et al. Using technology to maintain the education of residents during the COVID-19 pandemic. J Surg Educ. 2020;77(4):729-732. doi:10.1016/j.jsurg.2020.03.018

7. Tomlinson SB, Hendricks BK, Cohen-Gadol AA. Innovations in neurosurgical education during the COVID-19 pandemic: is it time to reexamine our neurosurgical training models? J Neurosurg. 2020;1 (aop):1-2.
8. Tricco ACLE, Zarin W, O'Brien KK, et al. PRISMA extension for scoping reviews (PRISMAScR): checklist and explanation. Ann Intern Med. 2018;169(7):467-473. doi:10.7326/M18-0850

9. Stambough JB, Curtin BM, Gililland JM, et al. The past, present, and future of orthopaedic education: lessons learned from the COVID-19 pandemic. J Arthroplasty. 2020;35(7):S60-S64. doi:10.1016/j.arth. 2020.04.032

10. Potts III JR. Residency and fellowship program accreditation: effects of the novel coronavirus (COVID-19) pandemic. J Am Coll Surg. 2020;230(6):1094-1097. doi:10.1016/j.jamcollsurg.2020.03.026

11. Vargo E, Ali M, Henry F, Kmetz D, Krishnan J, Bologna R. Cleveland Clinic Akron General Urology Residency Program's COVID-19 Experience. Elsevier; 2020.

12. Nassar AH, Zern NK, McIntyre LK, et al. Emergency restructuring of a general surgery residency program during the coronavirus disease 2019 pandemic: the University of Washington experience. JAMA Surg. 2020;155(7):624. doi:10.1001/jamasurg.2020.1219

13. Chong A, Kagetsu NJ, Yen A, Cooke EA. Radiology residency preparedness and response to the COVID-19 pandemic. Acad Radiol. 2020;27(6):856-861. doi:10.1016/j.acra.2020.04.001

14. Crosby DL, Sharma A. Insights on otolaryngology residency training during the COVID-19 pandemic. Otolaryngol Head Neck Surg. 2020;0194599820922502.

15. Alvin MD, George E, Deng F, Warhadpande S, Lee SI. The Impact of COVID-19 on Radiology Trainees. Radiological Society of North America; 2020.

16. Li Y, Zhao R, Zheng S, et al. Lack of vertical transmission of severe acute respiratory syndrome coronavirus 2, China. Emerg Infect Dis. 2020;26(6):1335-1336. doi:10.3201/eid2606.200287

17. Rakowsky S, Flashner BM, Doolin J, et al. Five questions for residency leadership in the time of COVID-19: reflections of chief medical residents from an internal medicine program. Acad Med. 2020; Publish Ahead of Print. doi:10.1097/ACM.0000000000003419

18. Amparore D, Claps F, Cacciamani GE, et al. Impact of the COVID-19 pandemic on urology residency training in Italy. Minerva Urol Nefrol. 2020;03868.

19. Accreditation Council for Graduate Medical Education. Summary of Changes to ACGME Common Program Requirements Section VI. Available from: http://www.acgme.org/What-We-Do/Accreditation/ Common-Program-Requirements/Summary-of-Proposed-Changes-toACGME-Common-Program-Requirements-Section-VI. Accessed August 5, 2020.

20. American Board of Radiology 2020. Coronavirus Information. Available from: http://www.theabr.org/announcements/coronavirusupdates. Accessed August 5, 2020.

\section{Publish your work in this journal}

Advances in Medical Education and Practice is an international, peerreviewed, open access journal that aims to present and publish research on Medical Education covering medical, dental, nursing and allied health care professional education. The journal covers undergraduate education, postgraduate training and continuing medical education including emerging trends and innovative models linking education, research, and health care services. The manuscript management system is completely online and includes a very quick and fair peer-review system. Visit http://www.dovepress.com/testimonials.php to read real quotes from published authors. 